\title{
THE PSYCHOLOGICAL FACTORS OF DETERMINATION OF THE LABOUR MIGRANTS' ADAPTATION STRATEGIES IN THE COUNTRY OF EMPLOYMENT
}

\section{Blynova O. Ye.}

\section{INTRODUCTION}

Increasing of the Ukrainians' labor emigration outside the country with the purpose of employment needs socio-psychological analysis of departure motives and migration behavior consequences for the personality, family, professional communities and Ukrainian society. Mostly, migration processes are studied in terms of economic (Cybul'skaja \& Krupin $^{1}$ ), sociological (Mikalauskiene \& Streimikiene \& Mazutaityte-Cepanoniene ${ }^{2}$ ) approaches and the Government migration policy but there is a lack of namely economic explanations since for the personality the consequences of Ukrainians' labor migration abroad are mostly negative.

From the moment of arrival in another country, migrants begin the process of entry, introduction, and settlement in a new society and state that includes organizational, legal, political, cultural and psychological aspects (Volodin \& Volodina \& Pitaikina ${ }^{3}$ ). In this whole process, different separate kinds of adaptation can be considered - political, economic, socio-organizational, labor, ethnic, religious, cultural, informational, educational, and psychological (Manolo Abella ${ }^{4}$ ). For migrants all kinds of adaptation are necessary. Besides, adaptation will

1 Цыбульская Ю. О., К Крупин В. Е. Трансграничная трудовая миграция сельского населения: особенности и пути решения проблем. Вестник экономической науки Украиныл. 2014. № 3 (27). С. 139-143.

2 Mikalauskiene A., Streimikiene D., Mazutaityte-Cepanoniene E. Employers' Openness to Labour Immigrants. Economics \& Sociology. 2017;10(3) DOI 10.14254/2071789X.2017/10-3/2.

3 Volodin V. M., Volodina N. V., Pitaikina I. A. Influence of labour migration processes on the quality of human capital of the Russian Federation. Vestnik Dagestanskogo Gosudarstvennogo Tehničeskogo Universiteta: Tehničeskie Nauki. 2017;44(1):173-185 DOI 10.21822/2073-6185-2017-44-1-173-185.

${ }^{4}$ Manolo Abella Effects of Labour Mobility: An Analysis of Recent International Development Literature. International Indigenous Policy Journal. 2013; 4(3): 3. 
be different depending on the level it occurs; to what extent it affects the internal structure of the individual.

The psychological way of the adaptation process is centered not only on studying of adaption process difficulties in a different ethnic, cultural environment but also on practical problems of searching successful adaptation strategies of migrants in new living conditions.

The aim is to analyze the psychological factors of labor migrants' choice of adaptation strategy in a foreign cultural environment.

\section{The theoretical foundation of migrants' adaptation problem}

The psychological adaptation is considered as a process of establishment of optimal correlation of the individual to the environment while doing the man's inherent activity, which allows the individual to satisfy actual needs and achieve relevant significant goals (staying mentally and physically healthy), to provide correspondence of the man's mental activity, his behavior, and environment demands. The social adaptation can be understood in two ways (Konstantinov ${ }^{5}$ ). On one hand, it is a constant process of the personality's adapting to existing social relations, norms, patterns, traditions of the society in which the individual lives and acts. On the other hand, the social adaptation is the result of this process. Moreover, both sides (the man and the environment) are active. If in the process of interaction with the environmental world, the person faces the information, which contradicts his concepts, then a discomfort condition (the cognitive dissonance) emerges, that mobilizes the person to search for adaptive reactions. They can be the following: finding by the individual explanations, which justify the existent contradictions; a conscious filtration of the information; self-replacement by the individual of his own concepts ${ }^{6}$.

Analyzing the psychological characteristics of the labor migrants' adaptation in a different cultural environment we rely on the methodological approaches by K.O. Abulkhanova-Slavska ${ }^{7}$,

\footnotetext{
${ }^{5}$ Константинов В. В Адаптационный процесс и трудовая миграция. Пензенский психологический вестник. 2014. № 1 (2). С. 60-72.

6 Блинова О.С. Трудова міграція населення України у соціальнопсихологічному вимірі : монографія. Херсон : РІПО, 2011. 486 с.

7 Абульханова-Славская К. А. Психология и сознание личности. Москва Воронеж, 1999. 224 с.
} 


\section{Ye.I. Golovakha ${ }^{8}$, O.A. Donchenko ${ }^{9}$ ， N.M. Lebedeva ${ }^{10}$, G.U. Solda- tova $^{11}$, and T.M. Titarenko ${ }^{12}$.}

All migrants face difficulties while interacting with local people, whose behavior they cannot predict. The researchers consider a great number of parameters on which the favorable interaction between representatives of different cultures and ethnic groups depends: the territory, which can be common or "own" only for one of the groups; the duration of interaction (permanent, long-term, short-term); the aim (cooperation, co-habitation, study, leisure); the type of involvement in a social life (from participation to observation); the frequency and depth of contacts; the relative equality of status and rights; the quantity proportion (the majority - the minority); the apparent distinctive features (the language, religious, race).

The person's introduction into a different ethnic environment, his obtaining, as a representative of one nation, those or other cultural forms of another nation, which occurs in the process of interaction, is considered as a process of acculturation. At first, the acculturation was considered as a group-level phenomenon, later the concept of the psychological acculturation was introduced. If the acculturation is alterations in the culture of a group, then the psychological acculturation is a process of alterations in the psychology of an individual. In this case, the alterations of value orientations, role behavior, social concepts of the people, whose group is affected by the influence of the general acculturation, are meant. The main attention in such studies is paid to the analyses of the migrants' psychological wellness, psychic and mental health, and the success of adaptation is determined through a sense of

${ }^{8}$ Головаха Е. П., Панина Н. В. Национальная толерантность и идентичность в Украине: опыт применения шкалы социальной дистанции в мониторинговом социологическом исследовании. Социиологический журнал. 2006. № 3. С. 17-24.

9 Донченко О., Романенко Ю. Архетипи соціального життя і політика (глибинні регулятиви психополітичного повсякдення): Монографія. К. : Либідь, 2001. 334 с.

10 Лебедева Н. М., Татарко А. Н. Социально-психологические факторы этнической толерантности и стратегии межгруппового взаимодействия в поликультурных регионах России. Психологический журнал. 2003. Т.24. № 5. С. 31-44.

${ }^{11}$ Солдатова Г. У., Шайгерова Л. А., Калиненко В. К., Кравцова О. А. Психологическая помощь мигрантам: травма, смена культуры, кризис идентичности [для студ. высш. учеб. заведений, обучающихся по направл. и спец-тям психологии]. М. : Смысл, 2002. 479 с.

12 Титаренко Т. М. Життєвий світ особистості: у межах та за межами буденності : наук. вид. К.: Либідь, 2003. 376 с. 
consent, harmony with the immediate environment. The analyses of namely acculturation alterations are most brightly reflected in the scientists' appeal to the concept of a "cultural shock", or a transition shock, or cultural fatigue, or "acculturation stress".

G.U. Soldatova notices that most researchers of the cultural shock have tried to determine the difficulties faced by the migrants and the typical reactions to those or other situations ${ }^{13}$. The less attention was paid to the personal aspects of the cultural shock, the types of people who experience the shock to a more or less extent, the determinants of personal reactions, duration of the shock state, etc.

The important methodological issue is the proportion of the group and personal acculturation levels. For example, G.U. Soldatova, analyzing the viewpoints of the Canadian psychologist J. Berry, who has made a great contribution to the study of the migrants' adaptation processes, determines the two essential factors. Firstly, if at the level of the group, the changes occur in the social structure, political organization, economic relations, cultural features, then at the level of the personality, the behavior and consciousness phenomena (identity, values, and concepts) are transformed. Secondly, the acculturation of each individual is a unique process, which may not coincide with the group alterations. The important conclusion is followed from that: when studying and considering the psychological consequences of the acculturation process for the individual, the proportion of two measurements should be taken into account: 1) the evaluation of the alterations occurring at the group level, 2) the participation of separate individuals in these alterations.

The approach to the classification of the acculturation strategies by $\mathrm{J}$. Berry is well known and widely represented in the ethnopsychological researches. Assimilation - the migrant is oriented towards the identification with a new culture, assimilation of other cultural values and gradual replacement his own cultural values by them. Segregation (or separation) - the minority reject the majority culture and preserve their own cultural distinctive features. Marginalization - the migrant does not identify himself with either one or the other culture. That may

${ }^{13}$ Солдатова Г. У., Шайгерова Л. А., Калиненко В. К., Кравцова О. А. Психологическая помощь мигрантам: травма, смена культуры, кризис идентичности [для студ. высш. учеб. заведений, обучающихся по направл. и спец-тям психологии]. М. : Смысл, 2002. 479 с. 
be the result of the impossibility of maintaining his own cultural identity and the lack of desire to establish and develop positive relations with the group of the cultural majority. Integration is the preservation of one's own cultural heritage along with a benevolent attitude towards the culture of the majority ${ }^{14}$.

On the basis of studying and generalization of scientific approaches to the socio-psychological nature of the person's adaptation in a different cultural environment, the program of the empirical research based on the analyses and description of the acculturation strategies, adaptation types, factors, criteria and empirical indicators of the Ukrainian labor migrants' adaptation in the country of employment has been built.

\section{The results of the empirical research and discussion}

Beginning the research, we proceeded from the model of the sociopsychological and psychological migrants' adaptation in a foreign cultural environment (Fig. 1). We believe that a person, who has a mature complete identity (personal and social, in particular, professional, family role, ethnic), is characterized by better indicators of adaptability.

The personal identity manifests itself in the integrity and maturity of the individual; the empirical indicators are mental health; satisfaction with one's present state; satisfaction with relations with relatives, friends, colleagues, neighbors, executives.

The professional identity is determined by the following empirical indicators: the availability of a permanent work, correspondence of the content of work with the level of qualification and the specialty by education, the preservation or improvement of the social status (compared to the status in Ukraine), the satisfaction with a job payment, the awareness of perspectives and opportunities for the professional growth.

The family role identity is expressed by the sense of satisfaction that there is the possibility to help one's children or parents financially, to provide them with normal living conditions, that is, to fully perform one's family responsibilities, even at the cost of breaking real family relationships since the family has been left in Ukraine.

14 Блинова О.С. Психологічні проблеми трудової міграції населення України. Актуальні проблеми психології: збірник наукових пращь Інституту психології ім. Г.С. Костюка АПН України / За ред. С.Д. Максименка. Київ: Главник, 2008. T. 10. Ч. 8. С. $76-82$. 


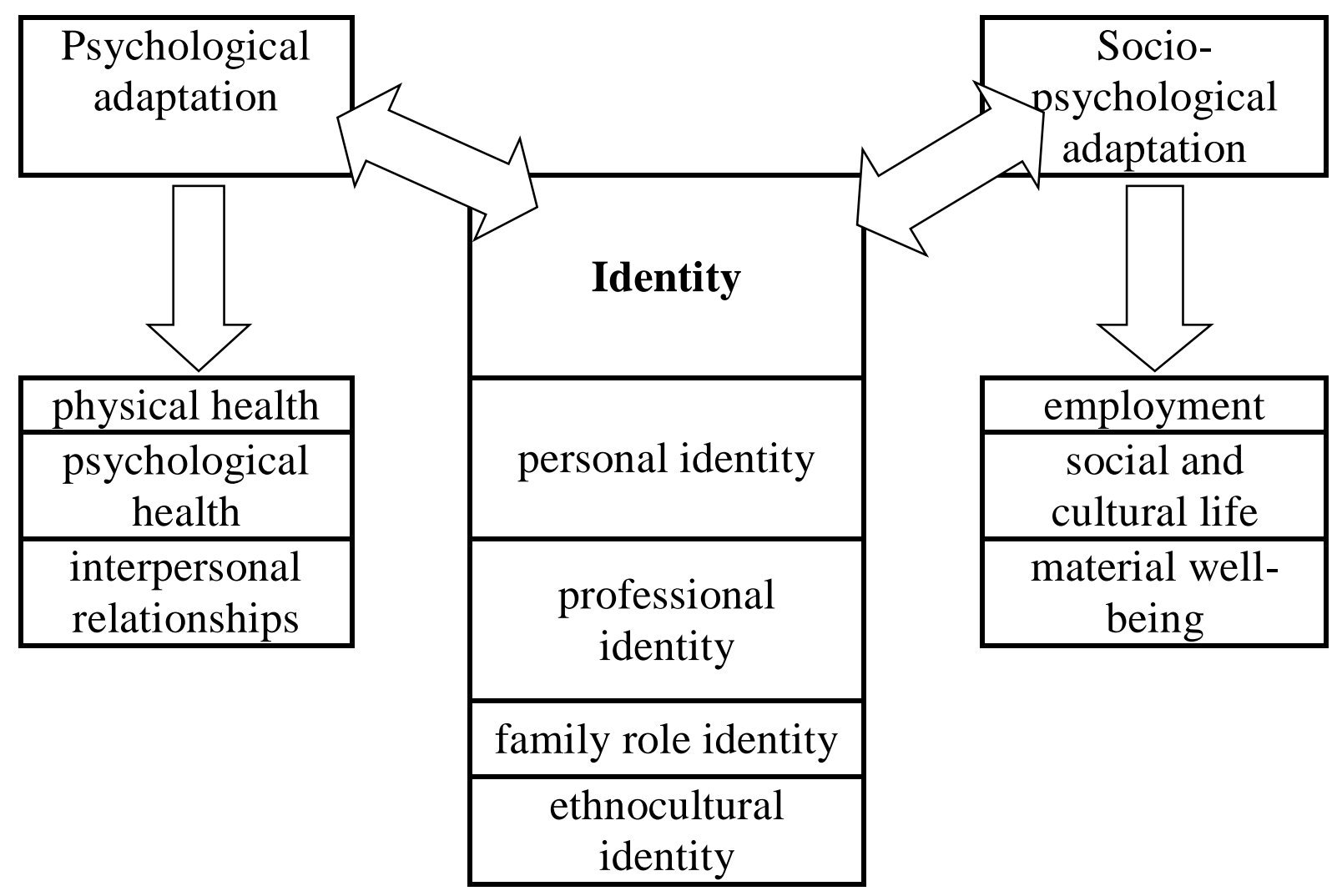

\section{Fig. 1. The interconnection of the labor migrants' identity and the psychological and socio-psychological adaptation criteria}

In norm, the ethnic identity has to be positive and connected with ethnic tolerance; this combination provides the choice of integration as the most positive strategy for the migrant's acculturation.

While entering a foreign social and cultural environment, a transformation, identity alteration occurs both within each type of the identity and in the identity system, which is caused by a need of the compensation and adaptation of the changed 'configuration' of the identity to new conditions.

In the empirical study the indicators of the psychological and sociopsychological adaptation of the labor migrants with the adaptation strategies have been correlated, 87 people (45 men $(51.7 \%)$ and 42 women $(48.3 \%)$ ), who have got their personal experience of employment abroad, have been involved in the study.

The research has consisted of the following stages: 1) the sociopsychological survey with the help of a questionnaire; 2) the identification of distinctive features and the typology of the identity of the Ukrainian labor migrants with the help of the techniques by L. B. Schneider "The definition of the personal identity" and "The 
definition of the professional identity"15. They allow to obtain information about the identity type: the diffuse identity; the identity crisis; the premature identity; the integral, mature identity; 3 ) the study of personal characteristics, which determine a success of the psychological and socio-psychological adaptation of the labor migrants of Ukraine in the country of employment with the help of "The fivefactor personal questionnaire" ("Big 5"), which includes the following factors: openness to experience, cnscientiousness, extraversion, agreeableness in relationships, neuroticism. The authors are R. McCrae, P. Costa, L.R. Goldberg ${ }^{16}$.

For the statistical processing of the results, the factor analysis was applied. The results were processed with the help of the statistical software package for the social sciences SPSS Statistics 19.0. The factor analysis was carried out by means of the principal components method, the rotation method - Varimax. The five main components have been obtained, which in total account for $85.7 \%$ of the dispersion of the signs.

Table 1

The factor structure of the psychological and socio-psychological adaptation components

\begin{tabular}{|l|c|c|c|c|c|}
\hline \multicolumn{1}{|c|}{ Components } & $\mathbf{1}$ & $\mathbf{2}$ & $\mathbf{3}$ & $\mathbf{4}$ & $\mathbf{5}$ \\
\hline $\begin{array}{l}\text { availability of work abroad } \\
\text { (permanent work - seasonal } \\
\text { or one-time work) }\end{array}$ & $\mathbf{. 8 7 4}$ & $\mathbf{. 3 0 4}$ & .213 & .067 & -.046 \\
\hline $\begin{array}{l}\text { measure of the coincidence } \\
\text { of profession and content of } \\
\text { work abroad }\end{array}$ & $\mathbf{. 8 8 3}$ & -.053 & $\mathbf{- . 3 7 1}$ & .062 & .124 \\
\hline personal identity & $\mathbf{. 6 8 2}$ & .341 & .076 & .118 & .123 \\
\hline $\begin{array}{l}\text { satisfaction with work } \\
\text { abroad (by questionnaire) }\end{array}$ & .238 & $\mathbf{. 7 6 7}$ & .026 & .037 & .113 \\
\hline $\begin{array}{l}\text { confidence in intercultural } \\
\text { communications }\end{array}$ & $\mathbf{. 7 4 5}$ & .208 & .132 & .034 & .056 \\
\hline
\end{tabular}

15 Шнейдер Л. Б. Личностная, гендерная и профессиональная идентичность: теория и методы диагностики. М. : Московский психолого-социальный институт, 2007. $128 \mathrm{c}$.

16 Хромов А.Б. Пятифакторный опросник личности: Учебно-методическое пособие. Курган: Изд-во Курганского гос. университета, 2000. 23 с. 


\begin{tabular}{|c|c|c|c|c|c|}
\hline Components & 1 & 2 & 3 & 4 & 5 \\
\hline $\begin{array}{l}\text { positive characteristics of a } \\
\text { typical Ukrainian (valency } \\
\text { of ethnic identity) }\end{array}$ & .613 & .018 & -.307 & .041 & -.016 \\
\hline $\begin{array}{l}\text { ethnic tolerance (average } \\
\text { score) }\end{array}$ & .167 & .787 & .141 & .017 & .007 \\
\hline professional identity & .717 & .154 & -.421 & .108 & .075 \\
\hline $\begin{array}{l}\text { rank of family } \\
\text { relevance(relevance of } \\
\text { family identity) }\end{array}$ & .103 & .217 & .571 & .096 & .028 \\
\hline openness to experience & .711 & .194 & .054 & .033 & .051 \\
\hline $\begin{array}{l}\text { self-control } \\
\text { (conscientiousness, } \\
\text { consciousness) }\end{array}$ & .287 & .673 & .111 & .025 & .102 \\
\hline extraversion & .631 & .269 & .034 & .017 & .078 \\
\hline $\begin{array}{l}\text { propensity to agreeableness, } \\
\text { benevolence }\end{array}$ & .254 & .708 & .182 & .104 & .007 \\
\hline $\begin{array}{l}\text { satisfaction with work } \\
\text { (career) }\end{array}$ & .345 & .689 & .117 & .004 & .231 \\
\hline $\begin{array}{l}\text { satisfaction with personal } \\
\text { achievements }\end{array}$ & .203 & .148 & .086 & .821 & .114 \\
\hline satisfaction with health & .023 & .087 & .148 & .637 & .178 \\
\hline $\begin{array}{l}\text { satisfaction with } \\
\text { communication with } \\
\text { friends, relatives }\end{array}$ & .194 & .278 & -.703 & .112 & .005 \\
\hline $\begin{array}{l}\text { support (external and } \\
\text { internal) }\end{array}$ & .312 & .779 & .043 & .144 & .079 \\
\hline optimism & .661 & .201 & -.027 & .029 & .042 \\
\hline tension & .052 & .128 & -.768 & .243 & .311 \\
\hline self-control & .609 & .073 & .227 & .008 & .119 \\
\hline negative emotio & .048 & .211 & -.534 & .207 & .142 \\
\hline life & .687 & .098 & .046 & .171 & .109 \\
\hline life process & .268 & .204 & -.196 & .506 & .130 \\
\hline life effective & .155 & .045 & -.237 & .054 & .796 \\
\hline locus of control - I & .712 & .038 & .112 & .069 & .033 \\
\hline locus of control - Life & .164 & .089 & -.357 & .167 & .763 \\
\hline Dispersion, $\%$ & 31.877 & 25.011 & 11.335 & 8.995 & 8.547 \\
\hline$\sum$ dispersion, $\%$ & 31.877 & 56.888 & 68.223 & 77.218 & 85.765 \\
\hline significance & 6.802 & 3.951 & 2.544 & 1.593 & 1.553 \\
\hline
\end{tabular}

Note: The load of the significant variables is highlighted in bold 
Having analyzed the obtained factors, we believe that the first three of them (explain $68.2 \%$ of the total dispersion) can be correlated with the three strategies of the migrants' adaptation in other socio-cultural conditions: integration, assimilation, and marginalization. In our opinion, there are two main options for resolving the crisis of the social and personal identity of the Ukrainian labor migrants in a foreign sociocultural environment, which lead to the transformation of the identity system to the changed conditions; they are integration and assimilation.

"Integration" is understood as an equal, parity inclusion in new socio-cultural conditions, when the person preserves the positive evaluations of his own cultural and ethnic identity and, as well, respects the traditions, habits, and norms of the country of employment. It is "integration" that gives every reason to preserve the professional affiliation, and, therefore, professional consciousness, for the internal harmonization, coherence, balanced integrity of personal characteristics, that is, for the preservation of the professional and personal identity.

"Assimilation" implies "dissolution" in another culture, almost a loss of the ethnic originality, which in extreme cases can be expressed in the aspiration, even in everyday life, to use the language of the country of employment, to dress, communicate, and celebrate in the same way, as it is customary in the host country. It can be presumed, that assimilation, as a strategy for the migrant's adaptation in the country of employment, does not contribute to the preservation (or establishment) of the positive professional identity, and, is inherent in the people, who do not have any special professional education, have not worked by specialty, therefore, agree on any low-skilled hard work.

The strategy of "marginalization" leads to an intensification of the identity crisis, which is manifested in psychological distress, dissatisfaction with one's own social status, professional achievements, family status, and personality.

Factor 4 and factor 5 have been interpreted more complicatedly and ambiguously, but they can also be explained as certain variants of the adaptation strategies of the labor migrants in the country of employment.

Factor 1 has the highest load or the highest informativeness (explains $31.8 \%$ of the dispersion), we believe, that according to the proposed theoretical model, this factor can be identified as "integration". Its positive pole is determined by the positive poles of the variables: "availability of work abroad; permanent work" (.874); "measure of the coincidence of 
profession and content of work abroad" (.883); "professional identity" (.717); "confidence in intercultural communications" (.745); "locus of control - I" (.712); "openness to experience" (.711); "goals in life" (.687); "personal identity" (.682); "optimism" (.661); "extraversion" (.631); "ethnic identity" (.612). The negative pole is determined by the opposite poles of the indicated variables.

First of all, this factor is determined by the two variables: "availability of work abroad (permanent work - seasonal work)" and "measure of the coincidence of profession and content of work abroad", that is, the labor migrants, who work by their profession and at a permanent work, most successfully adapt to new socio-cultural conditions, choosing the strategy of "integration". This factor with high factor load includes the positive mature professional identity, that is, the labor migrant, who is well aware of himself as a representative of a certain professional group, has a positive attitude to it, works by specialty, has the opportunity to achieve his professional goals, more effectively adapts abroad - he is "equal among equals", preserves his professional self-respect and believes that the exchange of experiences between Ukraine and European countries is quite real. It should be noticed that this factor includes the positive ethnic identity, that is, for the migrants, who integrate into a foreign cultural environment, it is typical to maintain a positive attitude towards their belonging to the "Ukrainianity", high estimation of Ukraine as a state and its perspectives of development. This combination of features provides the emigrant's confidence in the situations of intercultural communication and, with a high level of professional and ethnic identity, the positive mature personal identity.

It should be noticed that the variables "satisfaction with work" (.345) and "social support" (.312) are included in the first factor "Integration" with a rather low factor load, that shows that the orientation to the possibility of earning abroad "good money" and the availability of the migrants' social networks in this case for the successful adaptation of the Ukrainian labor migrants are not the determining factors (in our further analysis, we will see that these two variables have been included in the "assimilation" factor).

Factor 2 (informativeness $25.01 \%$ ): the positive pole is determined by the variables - "support" (.779); "satisfaction with work abroad (according to the questionnaire)" (.767); "propensity to agreeableness, 
benevolence" (.708); "satisfaction with work, career" (.689); "selfcontrol" (.673). The negative pole is determined by the factor "ethnic tolerance" (-.787), we can notice, that according to the methodological procedure of obtaining information in the scale of the social distance by Bogardus, the less is the indicator value, the higher is the level of the ethnic tolerance. In our opinion, this factor can be called "assimilation".

In the factor "assimilation" with an insignificant factor load, besides the above mentioned ones, the variable "availability of work abroad (permanent - seasonal or one-time work)" is included (.304), which allows to state that to the labor migrants, who choose the assimilation strategy, it is typical to have a permanent, not seasonal work, but its content does not coincide with the specialty of the person, it is mostly a low-skilled work.

The variable "satisfaction with work abroad" is included in the second factor "assimilation", since the content of the proposed variants of answers to this question in the questionnaire underlines the forced acceptance of the situation with work abroad, even if we have got quite a high score for this indicator: "Are you satisfied with the fact that you work abroad?" - "yes, this is the only opportunity to earn money for the family"; "yes, it's still better than to work in Ukraine now"; "yes, it's an opportunity to see how we should work and live" and so on. The negative pole of this variable in the "assimilation" factor shows the nonacceptance of working abroad: "no, because the attitude towards the Ukrainians only as a "cheap labor"; "no, I really miss my family and close people, who have been left behind in Ukraine"; "no, this is a forced measure, but we have to stand it for the family's sake" and so on. That gives us the foundation to believe that with such an attitude to work outside of Ukraine, the migrant is not likely to choose assimilation.

"Propensity to agreeableness" has been included in the second factor with a high factor load, since this is the personal feature that indicates the conformal ways of responding and adapting: benevolence, propensity to work in a group, group orientation, group goals, and norms, etc.; it provides the individual with the opportunity to become "like everyone else", "to dissolve in the community", to acquire the common features and ways of behavior in everyday situations, at home and work.

One should also pay attention to the high factor load of the "support" indicator - the migrant assimilates faster if he has friends, 
good acquaintances, including among local residents, if he establishes good relations with neighbors, colleagues, employers, etc., that is, he has the opportunity to receive various kinds of support - informational, emotional and instrumental.

The second factor includes the variable "self-control", the title of which is specified as consciousness, conscientiousness, responsibility, reliability, diligence, this variable reflects the degree of organization and motives of an individual in activities, we can assume that the migrant, assimilating, aspires to perform his work as best as possible, to have no accusations, to earn money and not to attract too much attention.

To this, the high factor load of the variable "ethnic tolerance" (-787) should be added at a very low factor load of the variable "ethnic identity" (.018), which is quite consistent with the model of determination of the personality's adaptation strategies in a different cultural environment proposed by J. Berry. This correlation of the ethnic identity (-) with ethnic tolerance $(+)$ characterizes the assimilation itself.

Factor 3 explains $11.3 \%$ of the dispersion, the positive pole of this factor is determined by the variable - "relevance of the family identity" (.571); the negative pole is described by the variables: "tension" (-.768); "satisfaction with communication with close people" (-.703); "negative emotions" (-.534). Besides, with not a high factor load, but, in our opinion, quite indicative, the following variables have also entered the negative pole of this factor - "professional identity" (-.421); "measure of the coincidence of the profession and content of work abroad" (-.371); "locus of control - Life" (-.357); "ethnic identity (valency)" (-.307). So, we can interpret this factor as "marginality".

In the content of this factor, the family identity plays the main part, which is included in the positive pole with a high factor load (.571), which underlines the relevance and significance of the family affiliation and the family value for the migrant, while the variable "satisfaction with communication with close people" (-.703) has a high but negative factor load, that indicates a conflict of the migrant's personal sphere, so there is a contradiction between the aspiration to help his family financially, but for that it is necessary to part with it, and the aspiration to be together with the family. This factor includes the variables "tension" (-.788) and "negative emotions" (-.534), that clearly demonstrates the reduction of the migrants' psychological well-being level. Since the psychological well-being is a criterion of the success of 
the psychological adaptation in the country of employment, that gives grounds to talk about the state of psychological disadaptation, which is accompanied by emotional disorders. The marginal position of the migrant is determined by his opinion of the general fatality of the human destiny, the inability of a person to manage the events of one's own life, to build one's life independently; such conclusions are confirmed by the factor load of the variable "locus of control - Life" (-.357). Besides, the variable "ethnic identity (valency of ethnic identity)" (-.307) has entered the factor "marginality" with a negative pole, which can indicate a mostly negative evaluation of the ethnic Ukrainian identity - the person is not able to find a decent work in Ukraine and has been unable to adapt in a foreign land.

Factor 4 determines $8.995 \%$ of the total dispersion, it is defined by the variables: "satisfaction with personal achievements" (.821) "health satisfaction" (.637) "process of life" (.506). Probably, this factor describes the individualized strategies of self-realization and adaptation abroad, combining a positive emotional evaluation of life, its meaningfulness due to one's own aspirations, efforts, real results; which are explained on the basis of the internal experience. The productivity and sense of satisfaction with life are intensified by a positive evaluation of one's own health.

It should be noticed that the indicator of the life-sense orientations "life process" with a moderate factor load is included in the 4th factor, while its absence in factors 1,2 and 3 is quite informative. The situation of working abroad is not considered as significant, meaningful, interesting and emotionally rich by either those labor migrants who adapt, applying the integration strategy to new sociocultural conditions or those who assimilate into a new culture. Especially those migrants who are in the marginal status and marginal position, who have not come yet to the resolution of their life and professional crisis and do not feel satisfied with the current period of life, apparently, hoping that the situation will be improved in the future.

Factor 5 has the informativity of $8.547 \%$ and is defined by the variables "life effectiveness" (.796) and "locus of control - Life" (.763), these variables explain the adaptation strategy of those migrants, who believe that life is generally managed by the person, only the person can determine and build one's own destiny, and therefore consider the past stage of their life to be productive. 


\section{CONCLUSIONS}

The strategies of the labor migrants of Ukraine in the country of employment are determined by the proportion, on the one hand, of the ethnocultural identity, and, on the other hand, recognition and respect for the values, norms, customs of another culture. On the basis of the combination of these two parameters, the following strategies of acculturation can be distinguished: integration, assimilation, separatism, marginalization. The integration has been recognized as the most successful strategy, which is the way to the multicultural society and it best contributes to the preservation of the positive ethnocultural identity of the labor migrants.

The determining factor, which distinguishes these strategies, is that the emigrant has a permanent work by specialty, which, in turn, promotes the formation of the mature positive professional identity. We have found out that the most influential factor of the success of the psychological adaptation of the labor migrant abroad is the availability of a permanent work, that coincides with the acquired specialty, gives a stable financial profit, respect of the surrounding people, meets the person's interests and expectations; and these are the factors that together provide the preservation of the mature positive personal identity. The strategy of assimilation, according to our data, is typical to the labor migrants, who are occupied at a low-skilled, hard, low profile work, have a diffuse professional identity, uncertain professional goals, values, perspectives. This group of Ukrainian labor migrants is characterized by a high level of ethnic tolerance towards representatives of the country of employment, and, at the same time, their ethnic identity is contradictory and unstable. The choice of this very strategy of adaptation is determined by such personal qualities as benevolence, conformity, the propensity to agreeableness, conscientiousness, diligence, responsibility, thoroughness.

In the case of the labor migrants' marginalization in the country of employment, the availability of a one-time or seasonal work, the content of which does not coincide with the person's specialty at all, is observed, as well as a significant intensification of the crisis of the family role identity, the valency reduction of the ethnic identity, which acquires negative features. The labor migrant's staying in the marginal position intensifies intrapersonal conflicts, is accompanied by emotional disorders, tension, psychological disadaptation. 
The integration strategy is characterized by the positive ethnic identity, that is, the Ukrainian migrants maintain a high level of the ethnic self-esteem, highly evaluate socio-economic opportunities and perspectives of the development of Ukraine as a state; which promotes the equal exchange of various economic, social and cultural experiences between Ukraine and other countries. The strategy of assimilation is characterized by a high level of ethnic tolerance; that is, the representatives of other ethnocultural groups, in particular, of the country of the migrant's residence, obtain, from the point of view of the migrant, higher estimations (compared to Ukrainians).

The personal identity acquires the features of a mature positive one when the labor migrant integrates into a foreign cultural environment of the country of employment. It has been found out, that the mature positive social identity of the Ukrainian labor migrants is interconnected with such personal characteristics: cognitive (openness to experience); motivational (certainty of goals in life); emotional (optimism); communicative (extraversion); volitional (internal locus of control; self-control).

If the migrant chooses the assimilation strategy, the personal identity tends to approach a diffuse, "unclear" identity with uncertain life goals, a reduced level of self-respect, a lack of internal integrity and coherence. The marginal position of the labor migrant in the country of employment leads to an intensification of the crisis of the personal identity when the migrant is not satisfied with the situation of work abroad, but in Ukraine, he also does not see any opportunities for self-realization.

The perspective of further research, we see in the development of the programs of prevention and overcoming the negative consequences of the labor migration for the individual.

\section{SUMMARY}

The article deals with the problem of the psychological factors of determination of the adaptation strategies of the Ukrainian labor migrants abroad. On the basis of the empirical research, it has been proved, that such strategies of acculturation of the labor migrants in a foreign cultural environment, such as integration and assimilation, contribute to resolving the crisis of the personal and social identity; the strategy of marginalization leads to an intensification of the crisis.

An important factor in preserving of the Ukrainian labor migrants' professional identity is the employment abroad by their specialty at a 
permanent work, that provides the opportunities for professional growth, satisfaction with their own self-realization, awareness of professional perspectives. In turn, a greater probability of getting a permanent work abroad and satisfaction with work are determined by the following personal qualities of the labor migrants: internality, self-control, conscientiousness, organization, responsibility, extraversion, openness to experience.

\section{REFERENCES}

1. Абульханова-Славская К. А. Психология и сознание личности. Москва - Воронеж, 1999. 224 с.

2. Блинова О.С. Трудова міграція населення України у соціально-психологічному вимірі : монографія. Херсон : РІПО, $2011.486 \mathrm{c}$.

3. Блинова О.С. Психологічні проблеми трудової міграції населення України. Актуальні проблеми психології: збірник наукових праџь Інституту психології ім. Г.С. Костюка АПН України / За ред. С.Д. Максименка. Київ: Главник, 2008. Т. 10. Ч. 8. С. 76-82.

4. Головаха Е. П., Панина Н. В. Национальная толерантность и идентичность в Украине: опыт применения шкалы социальной дистанции в мониторинговом социологическом исследовании. Соииологический журнал. 2006. № 3. С. 17-24.

5. Донченко О., Романенко Ю. Архетипи соціального життя i політика (глибинні регулятиви психополітичного повсякдення): Монографія. К. : Либідь, 2001. 334 с.

6. Константинов В. В Адаптационный процесс и трудовая миграция. Пензенский психологический вестник. 2014. № 1 (2). C. 60-72.

7. Лебедева Н. М., Татарко А. Н. Социально-психологические факторы этнической толерантности и стратегии межгруппового взаимодействия в поликультурных регионах России. Психологический журнал. 2003. Т.24. № 5. С. 31-44.

8. Солдатова Г. У., Шайгерова Л. А., Калиненко В. К., Кравцова О. А. Психологическая помощь мигрантам: травма, смена культуры, кризис идентичности [для студ. высш. учеб. заведений, обучающихся по направл. и спец-тям психологии]. М. : Смысл, $2002.479 \mathrm{c}$.

9. Титаренко Т. М. Життєвий світ особистості: у межах та за межами буденності : наук. вид. К.: Либідь, 2003. 376 с. 
10. Хромов А.Б. Пятифакторный опросник личности: Учебнометодическое пособие. Курган: Изд-во Курганского гос. университета, 2000. 23 с.

11. Шнейдер Л. Б. Личностная, гендерная и профессиональная идентичность: теория и методы диагностики. М. : Московский психолого-социальный институт, 2007. 128 с.

12. Цыбульская Ю. О., Крупин В. Е. Трансграничная трудовая миграция сельского населения: особенности и пути решения проблем. Вестник экономической науки Украиныл. 2014. № 3 (27). С. 139-143.

13. Giovanni Di Lieto International Legal Realities of Migrant Labour Rights. Journal of Identity and Migration Studies. 2015; 9(2): 86-109

14. Manolo Abella Effects of Labour Mobility: An Analysis of Recent International Development Literature. International Indigenous Policy Journal. 2013; 4(3): 3.

15. Mikalauskiene A., Streimikiene D., Mazutaityte-Cepanoniene E. Employers' Openness to Labour Immigrants. Economics \& Sociology. 2017;10(3) DOI 10.14254/2071-789X.2017/10-3/2.

16. Graţiela Georgiana Noja, Simona Mirela Cristea, Atila Yüksel, Ciprian Pânzaru, Raluca Mihaela Drăcea Migrants' Role in Enhancing the Economic Development of Host Countries: Empirical Evidence from Europe. Sustainability. 2018;10(3):894 DOI 10.3390/su10030894.

17. Bunea Daniela, Ailenei Dorel Labour market flexibility in terms of internal migration. Annals of the University of Oradea: Economic Science. 2010;1(1):153-158.

18. Volodin V. M., Volodina N. V., Pitaikina I. A. Influence of labour migration processes on the quality of human capital of the Russian Federation. Vestnik Dagestanskogo Gosudarstvennogo Tehničeskogo Universiteta: Tehničeskie Nauki. 2017;44(1):173-185 DOI 10.21822/2073-6185-2017-44-1-173-185.

Information about the author: Blynova O. Ye. Doctor of Psychological Sciences, Full Professor, Head of the Department of General and Social Psychology

Kherson State University

27, Universytetska str., Kherson, 73003, Ukraine 